\section{South Africa row overshadows Mainz archaeology congress}

\section{Mainz, West Germany}

ONE year overdue, the embattled eleventh congress of the International Union of Prehistoric and Protohistoric Sciences (IUPPS) finally took place here last week, amid anti-apartheid protests and a boycott by some African and European researchers.

The rift within the archaeology and anthropology communities over apartheid in South Africa has, if anything, deepened since September last year, when the rival World Archaeological Congress was held in Southampton, England.

The row over South African participation began in September 1985, when the organizers of the Southampton congress succumbed to pressure from several quarters and decided to ban South African and Namibian scientists from the 1986 Southampton congress (see Nature 317, $754 ; 1985)$. The IUPPS, which had previously been the sponsor of the quinquennial meeting, told the Southampton organizers that the meeting had to be open to all, or it would risk losing IUPPS sanction. The organizers were unable in the end either to appease the IUPPS or reinvite the South Africans. The IUPPS Permanent Council decided in January 1986 to remove its blessing from the Southampton congress (see Nature 319, $524 ; 1986)$ and began planning a separate congress in Mainz.

The decision of the Southampton organizers to go ahead with their meeting,

\section{ICSU to Beijing}

Thн: International Council of Scientific Unions (ICSU) has moved the venue of its next general assembly, planned for next year in Japan, from Tokyo to Beijing, chiefly because of the requirements of the Japanese government of intending South African participants at the meeting. The decision was taken at the June executive committee meeting of ICSU, which learned that there had been an insufficient response to a request that South African participants should not be required to sign a declaration of their opposition to apartheid while applying for Japanese visas. This provision does not apply to others from South Africa wishing to visit Japan businessmen, for example - and apparently derives from the terms of a UN resolution (accepted by Japan) in favour of a boycott of South African sport and "culture". It is believed that the Science and Technology Agency of China will be able to assure free access to Beijing next year, although formal word to this effect has not been received. which came to be called the World Archaeological Congress (WAC), stemmed in part from their belief that archaeology requires the participation of researchers outside the industrialized West, which is why members of aboriginal groups such as eskimos and Native Americans, as well as scientists from many developing countries, were invited to the WAC. It was the participation of so many researchers from less-developed countries that brought the South Africa issue to the fore. A movement to boycott the Mainz meeting unless changes were made in the IUPPS constitution grew out of the Southampton meeting.

Despite statements by the organizers

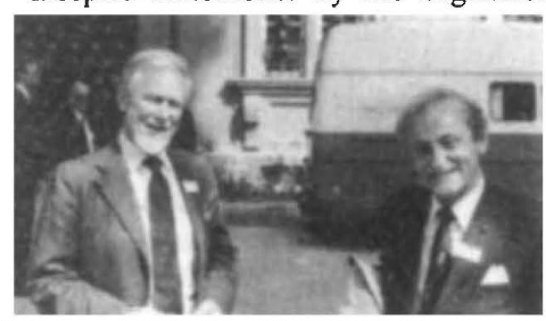

J. Desmond Clark and Phillip Tobias

here that participants are attending as individuals and not as members of national delegations, the presence of South Africans at both the congress and the IUPPS Permanent Council meetings has been enough to trigger a student protest and calls for a boycott. More significant is the withdrawal of several African countries such as Nigeria, Uganda and Angola.

The Mainz congress nevertheless drew 864 registered participants (as of 4 September), most of whom opposed any sort of boycott. There was a noticeable dearth of British researchers, according to John Yellen of the US National Science Foundation, but other developed nations, East and West, were amply represented. The relatively sparse turnout of US researchers was attributed by several people to scheduling difficulties. Others added that the substance of the Mainz meeting would not have been particularly interesting for most US archaeologists.

The high point of the meeting seems to have been the discussion on the prehistory of Africa held on 2 September, not least because of the paper by Phillip Tobias (Department of Anatomy, University of the Witswatersrand) on the origins of human speech. His conclusion, based on endocasts made from some early hominid fossils, that even Homo habilis had some sort of language capability, provoked vigorous discussion, especially among some younger participants with recent field experience.

Another successful session on Africa was led by J. Desmond Clark of the Uni-

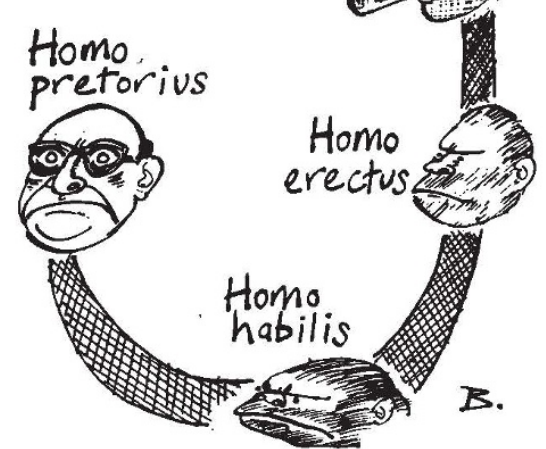

versity of California at Berkeley, who, together with Tobias, gave one of the two lectures that opened the Mainz conference. Clark's lecture dealt, among other things, with the question of how early man may have crossed from Africa into Europe - whether by land across the isthmus of Suez or by a variety of water routes. The land route seems the more likely, but Clark asserted that a water crossing would have been possible even at that early stage.

Congress organizer Konrad Weidemann admits that sections on the neolithic period and some other areas were weak, primarily because "half of the Romanians didn't show up". But he attributed their absence to financial rather than political reasons.

Virtually no Africans have come to Mainz. Congress organizer Konrad Weidemann of the Römisch-Germanisches Zentralmuseum in Mainz said this was entirely due to lack of finances, a statement disputed by advocates of a boycott.

The IUPPS plans to return to its fiveyear schedule with the 1991 congress, which will probably be held in Bratislava, Czechoslovakia. The Czech invitation, said Weidemann, includes the understanding that scientists of all nationalities, including South Africans, will be guaranteed access.

Some participants were nevertheless "lobbying hard" for changes in the IUPPS that would prevent the weakening of ties between European and African scientists. Amini Mturi of the Department of Antiquities of Tanzania is trying to get the IUPPS to implement three recommendations to ease the situation: an end to South African representation on the Permanent Council; an IUPPS condemnation of apartheid; and a review of the IUPPS statutes, which are generally acknowledged to be out of date. If Mturi fails in his attempt to influence the IUPPS to implement these changes, he said, "this might be my last congress". Furthermore, if Mturi fails, or even if he succeeds, Tanzania might ban any archaeologist who has worked in South Africa.

Steven Dickman 